\title{
Estimasi Produksi Tandan Kelapa Sawit Berdasarkan Analisis Ketersediaan Air dengan Teknik Oil Palm Dissection
}

\section{Estimation of Palm Bunch Production Based on Water Supply Analysis with Oil Palm Dissection Technique}

\author{
Sukarman $^{1}$, Herry Wirianata ${ }^{2}$, Kadarwati Budiharjo $^{2}$, Septa Primananda ${ }^{1}$, Susiana \\ Purwantisari $^{3 *}$ \\ ${ }^{1} R \& D$ Department, Wilmar International Plantation, Region Kalimantan Tengah, Indonesia \\ ${ }^{2}$ Magister Management Perkebunan, Fakultas Pertanian, Institute Pertanian STIPER (INSTIPER), Yogyakarta, Indonesia \\ ${ }^{3}$ Departemen Biologi, Fakultas Sains dan Matematika, Universitas Diponegoro, Jawa Tengah, Indonesia \\ *email: susiana_purwantisari@yahoo.co.id
}

\begin{abstract}
Abstrak
Jika faktor genetik, tanah dan teknik budidaya bukan merupakan faktor pembatas, maka fluktuasi hasil panen dipengaruhi oleh faktor iklim atau lingkungan. Penelitian ini bertujuan untuk mengetahui pengaruh ketersediaan air (defisit air, curah hujan dan hari hujan) terhadap sex ratio termasuk model hasil panen kelapa sawit. Penelitian telah dilakukan pada bulan November 2016 hingga Oktober 2017 di wilayah Wilmar International Plantation Kalimantan Tengah. Analisis menggunakan regresi berganda dan uji korelasi termasuk uji asumsi klasik (uji normalitas, multikolinieritas dan heteroskedastisitas) untuk analisis statistik dalam penelitian ini. Hasil penelitian menunjukkan bahwa curah hujan dan hari hujan berpengaruh nyata terhadap perkembangan sex ratio selama 23 bulan sebelum panen (MBH), saat defisit air berpengaruh nyata terhadap sex ratio pada $24 \mathrm{MBH}$. Estimasi distribusi produksi bulanan, anggaran produksi dan produksi aktual menunjukkan bahwa tidak signifikan. Estimasi distribusi produksi bulanan, anggaran produksi dan realisasi produksi menunjukkan bahwa tidak signifikan, dapat digunakan keakuratan distribusi produksi bulanan kelapa sawit.
\end{abstract}

Kata kunci: sex ratio, curah hujan, hari hujan, defisit hujan, bunga betina

\begin{abstract}
When the genetic, soil and cultivation technique are not limiting factors, the fluctuation of yield production is affected by the climate or environmental factors. The objective of this study is to observe the water availability effect (i.e., water deficit, rainfall, and rainy days) on the sex ratio, including the models of oil palm yield production. The study was carried out from November 2016 to October 2017 in the Wilmar International Plantation Region Central Kalimantan. Analysis using the multiple regression and correlation tests, including the classical assumption test (i.e., normality, multi-collinearity, and heteroscedasticity tests) for the statistical analysis in this study. The results show that the rainfall and rainy day significantly affect the sex ratio development during 23 months before harvest (MBH) when the water deficit significantly impacts the sex ratio at $24 \mathrm{MBH}$. While the estimation of distribution monthly production, budget production, and actual production was not significantly affected. Therefore, it can be used to estimate the monthly distribution production of oil palm accurately.
\end{abstract}

Keyword: sex ratio, rainfall, a rainy day, water deficit, female flower

\section{PENDAHULUAN}

Perkembangan dan pertumbuhan kelapa sawit dipengaruhi oleh faktor genetik tanaman, lingkungan dan teknik budidaya. Pada kondisi dimana genetik bahan tanaman, teknik budidaya dan tanah bukan merupakan faktor pembatas, maka keragaman yang terjadi hanya dipengaruhi oleh faktor lingkungan (iklim). Kondisi cekaman air berdampak terhadap penurunan pembentukan dan pembentangan daun sehingga mengganggu proses fotosintesis dan penurunan produktivitas tanaman, serta menyebabkan penurunan efektivitas pemupukan karena air berperan langsung dalam melarutkan unsur hara yang diserap oleh tanaman.

Kelapa sawit termasuk kelompok pohon berumah satu (monocious), artinya dalam satu pohon terdapat bunga jantan dan bunga betina (Prasetyo dan Agus, 2012). Kemunculan pelepah dan bunga dipengaruhi oleh variasi iklim (Hoffman et al., 2014) dan faktor genetik (Legros et al., 2009a). Waktu yang diperlukan dari pembentukan bunga sampai matang fisiologis ditentukan oleh faktor iklim, sehingga waktu dalam pembentukan buah pada berbagai wilayah akan 
berbeda. Fase awal pembungaan kelapa sawit dimulai oleh fase inisiasi bunga kemudian mengikuti tahapan perkembangan bunga yang tersaji pada tabel 1 .

Tabel 1. Tahap perkembangan komponen buah pada kelapa sawit menghasilkan (Sumber: Breure, 2003)

\begin{tabular}{|c|c|c|}
\hline Bulan & $\begin{array}{l}\text { Posisi } \\
\text { Daun }\end{array}$ & Tahap Perkembangan \\
\hline 0 & -40 & Penentuan bakal bunga \\
\hline $7-11$ & -26 to -18 & Penentuan spikelet \\
\hline $11-16$ & -18 to -12 & $\begin{array}{l}\text { Penentuan jumlah bunga per } \\
\text { spikelet dan pembentukan } \\
\text { kelamin }\end{array}$ \\
\hline $15-18$ & -10 to -4 & $\begin{array}{l}\text { Penampakan spikelet primordia } \\
\text { pertama (perkembangan } \\
\text { spikelet) }\end{array}$ \\
\hline $18-19$ & -3 to -2 & $\begin{array}{l}\text { Perkembangan bunga jantan dan } \\
\text { betina }\end{array}$ \\
\hline $22-24$ & +7 to +8 & Peka aborsi \\
\hline $24-25$ & +9 to +10 & $\begin{array}{l}\text { Batang dan spikelet bunga } \\
\text { terbentuk }\end{array}$ \\
\hline $28-31$ & +17 to +20 & Anthesis \\
\hline $32-34$ & +24 to +27 & Buah terbentuk \\
\hline $35-36$ & +28 to +32 & Matang panen \\
\hline
\end{tabular}

Hidayat et al., (2013a) menyatakan bahwa curah hujan yang ideal bagi pertumbuhan kelapa sawit sekitar 1.750 - $3000 \mathrm{~mm} /$ tahun dengan distribusi sepanjang tahun, tidak terdapat bulan kering berkepanjangan, curah hujan di bawah 120 $\mathrm{mm}$ /bulan, dan tidak terdapat bulan basah dengan hujan > 20 hari. Menurut Murtilaksono et al., (2007) kelapa sawit membutuhkan air paling sedikit 150 $\mathrm{mm} /$ bulan atau 5-6 mm/hari. Musim kering dan defisit air sangat besar pengaruhnya terhadap produktivitas kelapa sawit yaitu mempengaruhi lama proses kematangan tandan sehingga akan mengurangi jumlah TBS yang dihasilkan. Nawfetrias (2015) juga berpendapat bahwa rasio bunga jantan terhadap bunga betina ini dipengaruhi oleh faktor cekaman air. Kondisi cekaman tersebut terjadi apabila defisit air mencapai $200 \mathrm{~mm}$ pada tanaman kelapa sawit (Siregar et al., 1995; Djufry, 2000). Defisit air pada kelapa sawit tidak hanya terjadi saat kondisi curah hujan rendah tetapi juga pada kondisi curah hujan tinggi dengan periode bulan kering yang panjang (Rahutomo, 2007).

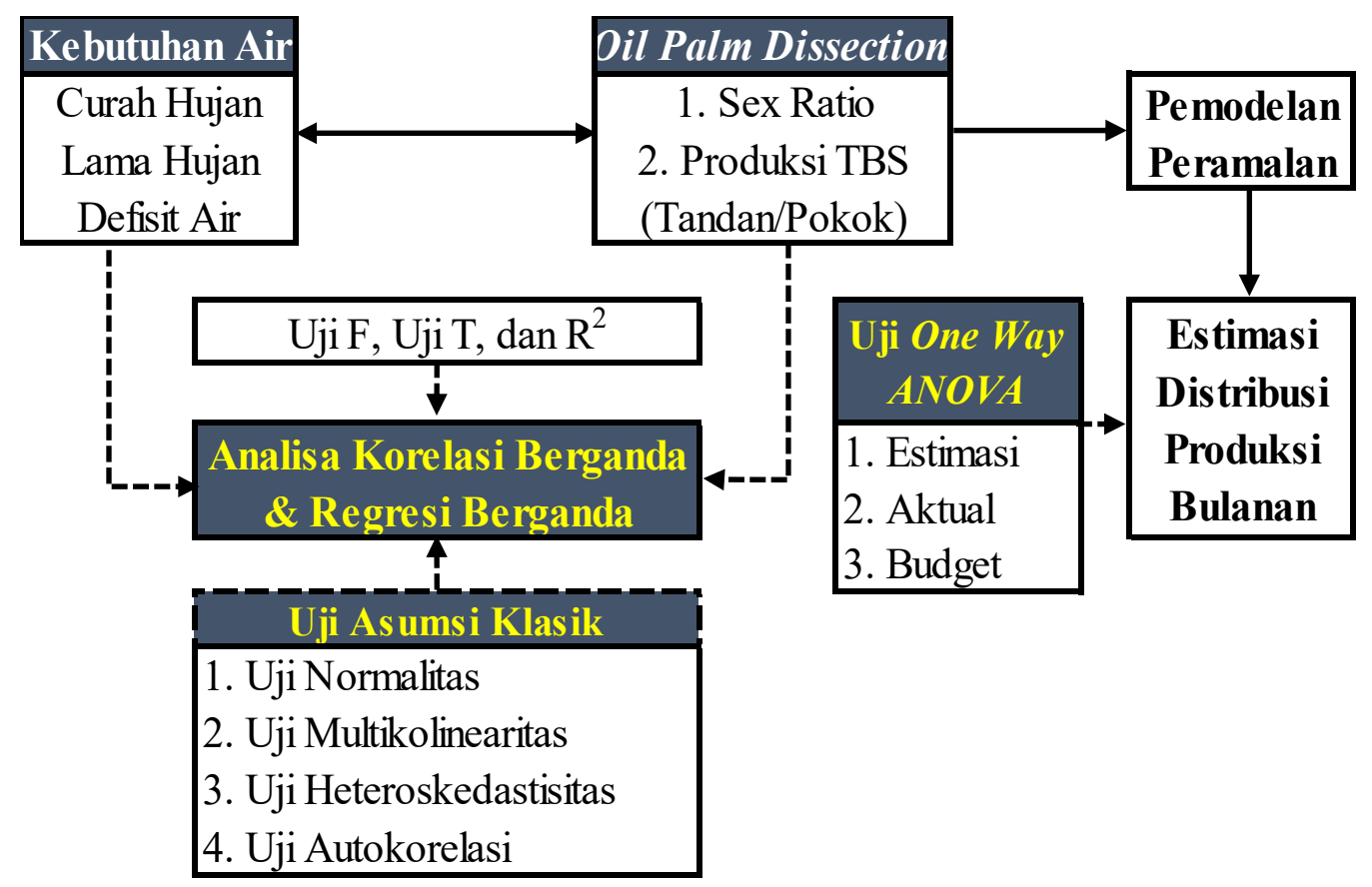

Gambar 1. Titik-titik dan selang waktu yang rawan cekaman lingkungan pada tanaman kelapa sawit (dimodifikasi, Sumber: Breure, 2003; Siregar et al., 2005)

Menurut Hidayat et al., (2013b), estimasi produksi 6 bulanan dihitung menggunakan metode trossen telling, hal ini berbeda dengan estimasi produksi di lokasi penelitian yang dilakukan per 4 bulan menggunakan metode Black Bunch Census (BBC). Tujuan penelitian ini adalah untuk menganalisa 
pengaruh ketersediaan air (defisit air, curah hujan dan hari hujan) terhadap sex ratio bunga kelapa sawit dan membuat model estimasi distribusi produksi tandan kelapa sawit. Hasil penelitian dapat dimanfaatkan dalam 1) Sebagai referensi untuk membuat langkah penanganan dalam meningkatkan produksi kelapa sawit saat terjadi dan sebelum terjadi cekaman air; 2) Membantu dalam membuat perencanaan produksi kelapa sawit untuk menghitung tebutuhan tenaga panen, menghitung kebutuhan transportasi dalam pengangkutan tandan buah sawit (TBS), membuat rencana pengolahan di Pabrik Kelapa Sawit, dan menghitung rencana penjualan Crude Palm Oil (CPO).

\section{METODE}

Penelitian ini dilaksanakan pada bulan November 2016 - Oktober 2017 di Perkebunan kelapa sawit, Wilmar International Plantation - Region Kalimantan Tengah. Penelitian ini menggunakan metode eksperimental. Data primer menggunakan data OPD, sedangkan data sekunder meliputi: data rainfall, area statement, dan crop production. Analisa penelitian ini dijelaskan pada bagan di bawah ini.

Waktu Sebelum Panen (Bulan)

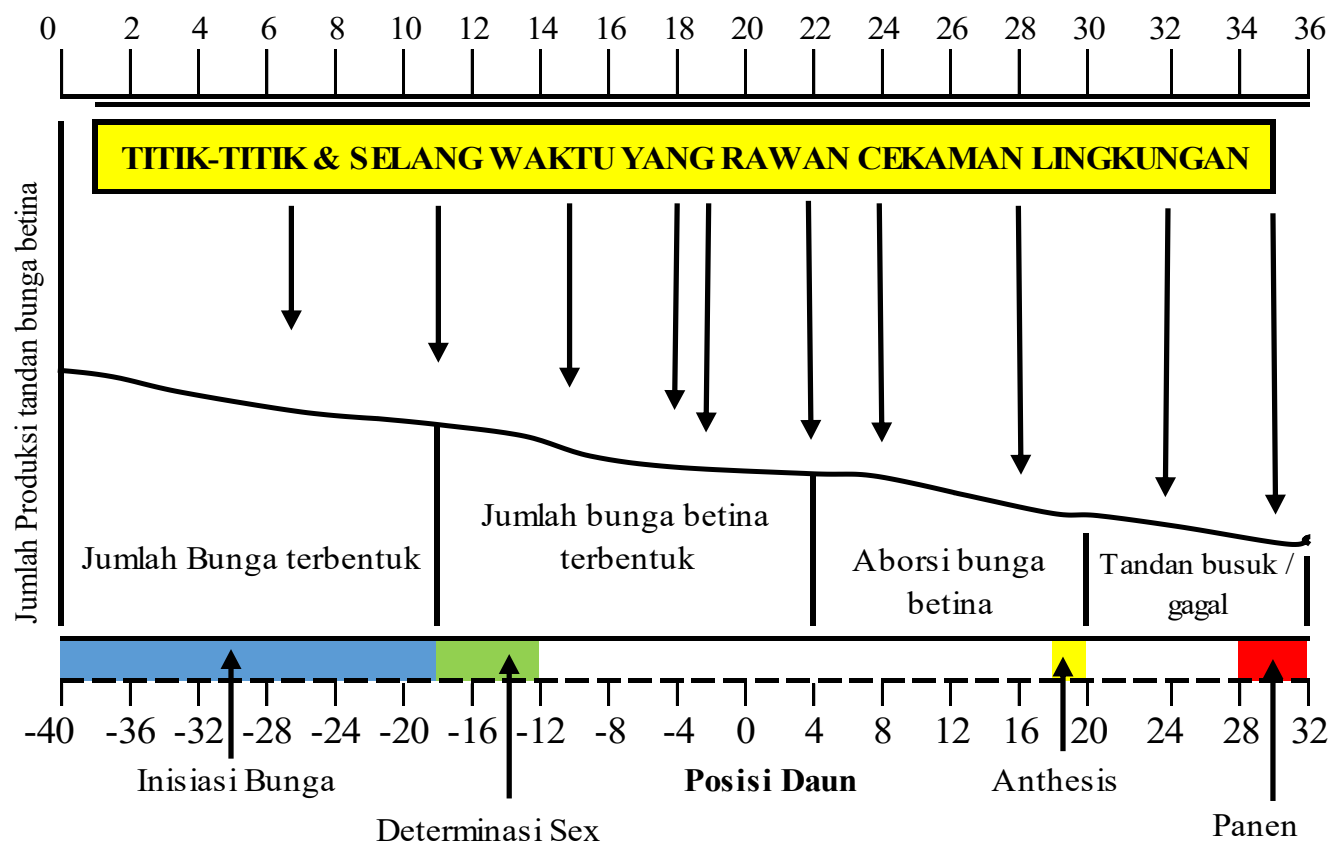

Gambar 2. Bagan analisa penelitian

\section{HASIL DAN PEMBAHASAN}

\section{Pemodelan Sex ratio Berdasarkan Oil Palm Dissection}

Oil palm dissection merupakan metode pembedahan pokok kelapa sawit untuk mengetahui sex ratio dan perkembangan bunga kelapa sawit. Bunga betina ini nantinya berpotensi berkembang menjadi tandan sehingga dapat digunakan sebagai dasar estimasi produksi dan estimasi distribusi produksi kelapa sawit bulanan selama periode 18 bulan selanjutnya. 

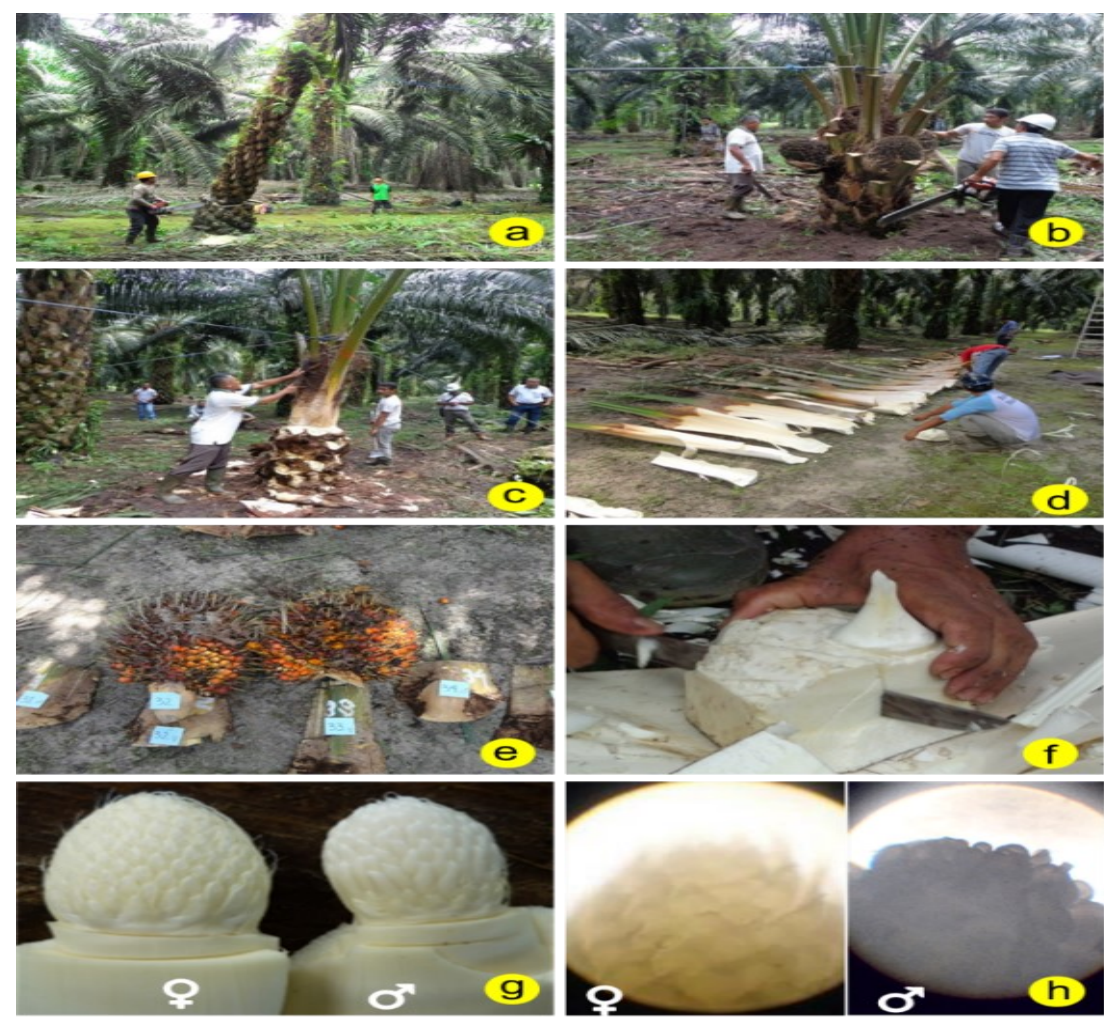

Gambar 3. Tahapan pelaksanaan kegiatan OPD: (a) penumbangan pada pokok sampel, (b) penomoran pelepah serta bunga, (c) pembedahan bunga \& buah, (d) dan (e) Penyusunan bunga serta buah berdasarkan urutan nomor pelepah, (f) pembedahan pelepah mulai dari pelepah 10 sampai pelepah - 18, (g) bunga jantan dan betina pada pelepah 14 dan 13 dilapangan, dan (h). bunga pada pelepah $-6 \&-7$.

Pemilihan 26 pokok dari blok sampel dipilih berdasarkan kombinasi antara luasan jenis tanah, tahun tanam, varietas tanaman dan lain-lain yang dominan di lokasi penelitian. Pokok yang dipilih merupakan pokok yang mewakili kondisi pokok sekitarnya, bukan pokok tepi jalan, pokok sisip, pokok sakit, ataupun pokok abnormal. Pokok sampel ditumbang kemudian dibedah untuk dihitung jumlah bunga dan tandan yang terbentuk. Semua tandan dan bunga $(\hat{\partial},+$ ) dicatat kedalam form sesuai dengan nomor pelepahnya. Pemodelan data OPD ke dalam sex ratio yaitu dengan memasukkan data bunga dan tandan sesuai nomor pelepah ke dalam bulan prediksi panen, sehingga diketahui persentase sex ratio dan jumlah bunga betina per pokok yang akan dipanen selama 18 bulan ke depan. Bulan prediksi panen berdasarkan estimasi pertumbuhan pelepah yaitu $2-$ 3 pelepah/bulan (Donough, 2012). Rerata pertumbuhan pelepah bulanan di lokasi penelitian sebesar $2.43 \mathrm{pelepah/bulan,} \mathrm{dibulatkan} \mathrm{menjadi} 2.5$ pelepah / bulan, angka tersebut yang digunakan sebagai dasar pembagi jumlah tandan per bulan dalam metode OPD. Pengamatan bunga jantan dan betina di lapangan hanya dapat dilakukan pada bunga yang masih dapat dibedakan dengan jelas antara jantan dan betina, selebihnya dilakukan di Laboratorium menggunakan bantuan mikroskop. Bunga jantan dan betina yang terbentuk diamati maksimal sampai pada pelepah -18 (rata-rata -12 sampai -14). Sex ratio dihitung berdasarkan perbandingan jumlah bunga betina dan tandan terhadap total bunga serta tandan yang terbentuk (tandan + bunga betina + bunga jantan + kosong atau bunga aborsi). Semakin tinggi sex ratio maka semakin banyak bunga betina, sehingga peluang untuk mendapatkan produksi tandan yang tinggi akan menjadi lebih besar (Hazriani, 2004). 
Tabel 2. Sex ratio hasil Oil palm dissection periode Jan 2017 - Jun 2018

\begin{tabular}{|c|c|c|c|c|c|c|c|c|c|c|c|c|c|c|c|c|c|c|c|}
\hline \multirow{2}{*}{$\begin{array}{l}\text { Number } \\
\text { Sample }\end{array}$} & \multicolumn{12}{|c|}{2017} & \multicolumn{6}{|c|}{2018} & \multirow{2}{*}{$\begin{array}{l}\text { Total } \\
\text { Tandan } \\
\text { (1.5 th) }\end{array}$} \\
\hline & Jan & Feb & Mar & Apr & May & Jun & Jul & Aug & Sep & Oct & Nov & Dec & Jan & Feb & Mar & Apr & May & Jun & \\
\hline 1 & 0 & 0 & 0 & 1.5 & 0.5 & 0 & 1.0 & 2.0 & 2.0 & 0 & 2.0 & 2.5 & 1.5 & 2.0 & 1.0 & 2.5 & 0.5 & 2.5 & 21.5 \\
\hline 2 & 2.5 & 2.5 & 1.5 & 0.5 & 1.5 & 2.5 & 2.5 & 2.0 & 2.0 & 2.5 & 2.5 & 1.0 & 0 & 1.5 & 2.5 & 2.5 & 0.5 & 1.0 & 31.5 \\
\hline 3 & 0 & 0 & 2.0 & 0.5 & 2.5 & 2.0 & 0 & 1.5 & 2.5 & 2.5 & 2.5 & 2.5 & 1.5 & 1.0 & 0 & 0 & 1.0 & 2.5 & 24.5 \\
\hline 4 & 0 & 2.5 & 0.5 & 0 & 2.0 & 1.5 & 2.5 & 2.0 & 0 & 1.5 & 2.5 & 2.5 & 2.5 & 1.0 & 0 & 2.5 & 0.5 & 1.5 & 25.5 \\
\hline 5 & 0 & 0 & 2.0 & 0 & 0 & 2.5 & 1.5 & 0 & 1.0 & 2.5 & 2.5 & 2.5 & 2.5 & 2.0 & 2.0 & 0 & 0 & 1.5 & 22.5 \\
\hline 6 & 0.5 & 0.5 & 2.0 & 2.5 & 0.5 & 0 & 0 & 2.0 & 2.0 & 1.0 & 0 & 0.5 & 2.5 & 2.5 & 2.5 & 2.5 & 0.5 & 0.5 & 22.5 \\
\hline 7 & 2.5 & 2.5 & 2.5 & 1.5 & 2.5 & 1.0 & 0 & 1.5 & 0.5 & 2.5 & 2.5 & 1.0 & 0 & 0.5 & 2.5 & 2.5 & 0.5 & 1.0 & 27.5 \\
\hline 8 & 2.5 & 1.0 & 1.0 & 2.5 & 2.5 & 2.5 & 1.5 & 2.0 & 2.0 & 2.5 & 2.5 & 2.5 & 1.5 & 0 & 0 & 0 & 1.0 & 1.0 & 28.5 \\
\hline 9 & 2.5 & 2.0 & 0 & 0 & 2.0 & 0 & 0 & 0 & 0 & 2.5 & 2.5 & 2.5 & 2.5 & 2.5 & 0.5 & 2.5 & 1.5 & 1.0 & 24.5 \\
\hline 10 & 0 & 0 & 1.0 & 1.0 & 1.0 & 1.5 & 2.5 & 1.0 & 0 & 0 & 0 & 1.5 & 1.0 & 1.0 & 1.0 & 1.0 & 1.0 & 1.0 & 15.5 \\
\hline 11 & 0 & 0 & 1.0 & 2.5 & 2.5 & 2.5 & 2.5 & 0 & 0 & 0 & 0 & 0.5 & 2.5 & 2.5 & 2.5 & 1.5 & 1.0 & 0 & 21.5 \\
\hline 12 & 1.0 & 0 & 0 & 2.5 & 1.5 & 0 & 0 & 1.5 & 1.5 & 0.5 & 2.5 & 0 & 1.0 & 2.5 & 1.5 & 0.5 & 1.5 & 0 & 18.0 \\
\hline 13 & 2.5 & 2.5 & 1.5 & 2.0 & 0 & 0 & 0 & 0 & 0 & 0 & 0 & 1.0 & 0 & 1.5 & 1.5 & 0 & 0 & 1.5 & 14.0 \\
\hline 14 & 1.0 & 2.5 & 1.5 & 2.5 & 2.5 & 0 & 0 & 2.5 & 2.5 & 2.5 & 2.5 & 2.5 & 0.5 & 1.0 & 1.0 & 1.5 & 0.5 & 0 & 27.0 \\
\hline 15 & 1.5 & 1 & 2.5 & 2.5 & 2.5 & 2.5 & 1.5 & 1.0 & 0 & 0.5 & 2.5 & 2.5 & 1.5 & 0 & 1.0 & 2.5 & 1.5 & 0.5 & 27.5 \\
\hline 16 & 0 & 1.5 & 2.5 & 2.5 & 2.5 & 0 & 0 & 0 & 0 & 0.5 & 2.5 & 2.5 & 2.5 & 0.5 & 0.5 & 0 & 1.0 & 0 & 19.0 \\
\hline 17 & 0 & 0 & 1.0 & 2.5 & 0.5 & 1.5 & 1.5 & 0 & 0 & 0 & 2.0 & 2.5 & 2.5 & 2.0 & 0 & 0 & 0 & 1.0 & 17.0 \\
\hline 18 & 0.5 & 0.5 & 2.5 & 2.5 & 1.5 & 0 & 0 & 0.5 & 2.5 & 2.5 & 2.5 & 2.0 & 0 & 0 & 0 & 2.5 & 2.5 & 0 & 22.5 \\
\hline 19 & 1.0 & 1.0 & 1.0 & 1.0 & 0.5 & 1.5 & 0.5 & 0 & 0 & 0 & 0 & 2.0 & 0 & 0 & 0 & 0.5 & 1.5 & 1.0 & 11.5 \\
\hline 20 & 0 & 0 & 0 & 2.0 & 1.0 & 2.5 & 2.5 & 2.5 & 0.5 & 0.5 & 2.5 & 1.0 & 2.0 & 1.0 & 2.0 & 1.0 & 0 & 0.5 & 21.5 \\
\hline 21 & 2.5 & 2.5 & 2.5 & 1.0 & 1.0 & 2.5 & 2.5 & 1.0 & 0 & 0 & 0 & 2.5 & 2.5 & 2.5 & 0.5 & 0 & 1.0 & 2.5 & 27.0 \\
\hline 22 & 2.5 & 2.5 & 2.5 & 2.0 & 0 & 0 & 0 & 0 & 0 & 0 & 0 & 2.5 & 2.5 & 2.0 & 0 & 0 & 0 & 2.5 & 19.0 \\
\hline 23 & 2.0 & 2.5 & 2.5 & 2.5 & 2.5 & 2.0 & 0 & 0 & 0 & 2.5 & 2.5 & 2.5 & 2.5 & 1.0 & 0 & 0 & 0 & 2.5 & 27.5 \\
\hline 24 & 0 & 1.5 & 2.5 & 0 & 0 & 1.0 & 0 & 0 & 0 & 0.5 & 2.5 & 2.5 & 2.5 & 2.5 & 2.5 & 0 & 0 & 1.0 & 19.0 \\
\hline 25 & 0 & 2.5 & 0.5 & 1.5 & 2.5 & 2.5 & 2.5 & 0 & 0 & 1.5 & 2.5 & 2.5 & 2.5 & 1.5 & 0.5 & 0 & 0 & 0.5 & 23.5 \\
\hline 26 & 1.0 & 2.0 & 2.0 & 2.5 & 2.5 & 0 & 0 & 2.0 & 0 & 2.5 & 2.5 & 2.5 & 0.5 & 0 & 0 & 0.5 & 1.5 & 2.5 & 24.5 \\
\hline Tandan/bulan & 1.0 & 1.3 & 1.5 & 1.6 & 1.5 & 1.2 & 1.0 & 1.0 & 0.7 & 1.2 & 1.8 & 1.9 & 1.6 & 1.3 & 1.0 & 1.0 & 0.7 & 1.1 & 22.5 \\
\hline Sex Ratio \% & 40 & 52 & 59 & 65 & 59 & 49 & 38 & 38 & 29 & 48 & 72 & 78 & 63 & 53 & 39 & 41 & 29 & 45 & \\
\hline Estimasi & & \multicolumn{4}{|c|}{ Moderate } & \multicolumn{5}{|c|}{ Moderately low } & & gh & \multicolumn{2}{|c|}{ Moderate } & \multicolumn{4}{|c|}{ Moderately low } & \\
\hline Status & \multicolumn{2}{|c|}{ High } & \multicolumn{4}{|c|}{ Moderately high } & \multicolumn{3}{|c|}{ Moderate } & \multicolumn{4}{|c|}{ Moderately low } & \multicolumn{2}{|c|}{ Low } & \multicolumn{3}{|c|}{ Very Low } & \\
\hline Tandan/Bulan & \multicolumn{2}{|c|}{2.5} & \multicolumn{4}{|c|}{2} & \multicolumn{3}{|c|}{2.5} & \multicolumn{4}{|c|}{1} & \multicolumn{2}{|c|}{0.5} & \multicolumn{3}{|c|}{$\mathbf{0}$} & \\
\hline
\end{tabular}

\section{Pengaruh Ketersediaan Air terhadap Sex ratio}

Hubungan dan pengaruh defisit air, curah hujan dan hari hujan terhadap sex ratio bunga kelapa sawit diteliti menggunakan analisa korelasi dan regresi berganda. Faktor lain seperti jenis tanah, lama penyinaran, pemupukan, kultur teknis dan lain sebagainya diasumsikan sama dan telah sesuai dengan SOP yang berlaku di perusahaan lokasi penelitian. Hasil uji $f$ pada regresi berganda menunjukkan nilai prob. F hitung (sig.) $0,017<0,05$ sehingga dapat menjelaskan bahwa model tersebut layak digunakan untuk menjelaskan pengaruh defisit air, curah hujan dan hari hujan terhadap sex ratio bunga kelapa sawit. Nilai R-Square sebesar 0,506 menunjukkan bahwa defisit air, curah hujan dan hari hujan terhadap sex ratio memiliki proporsi pengaruh sebesar $50,6 \%$.
Tabel 3. Korelasi defisit air, curah hujan dan hari hujan terhadap sex ratio

\begin{tabular}{llll}
\hline & Hari Hujan & Curah Hujan & Sex ratio \\
\hline Defisit Air & $.752^{* *}$ & $.688^{* *}$ & $.487^{*}$ \\
Hari Hujan & 1 & $.971^{* *}$ & .447 \\
Curah Hujan & 1 & $.534^{*}$
\end{tabular}

Ket :

$*$ = Terdapat hubungan pada taraf kepercayaan 5\% $* *=$ Terdapat hubungan pada taraf kepercayaan $1 \%$

Hasil analisa korelasi di atas menunjukkan korelasi yang cukup kuat antara defisit air dan curah hujan terhadap sex ratio pada taraf 0,05 . Korelasi pada masing-masing variabel independen menunjukan hubungan yang kuat antara defisit air terhadap hari hujan dan curah hujan serta hubungan yang sangat kuat pada variabel hari hujan terhadap curah hujan. 


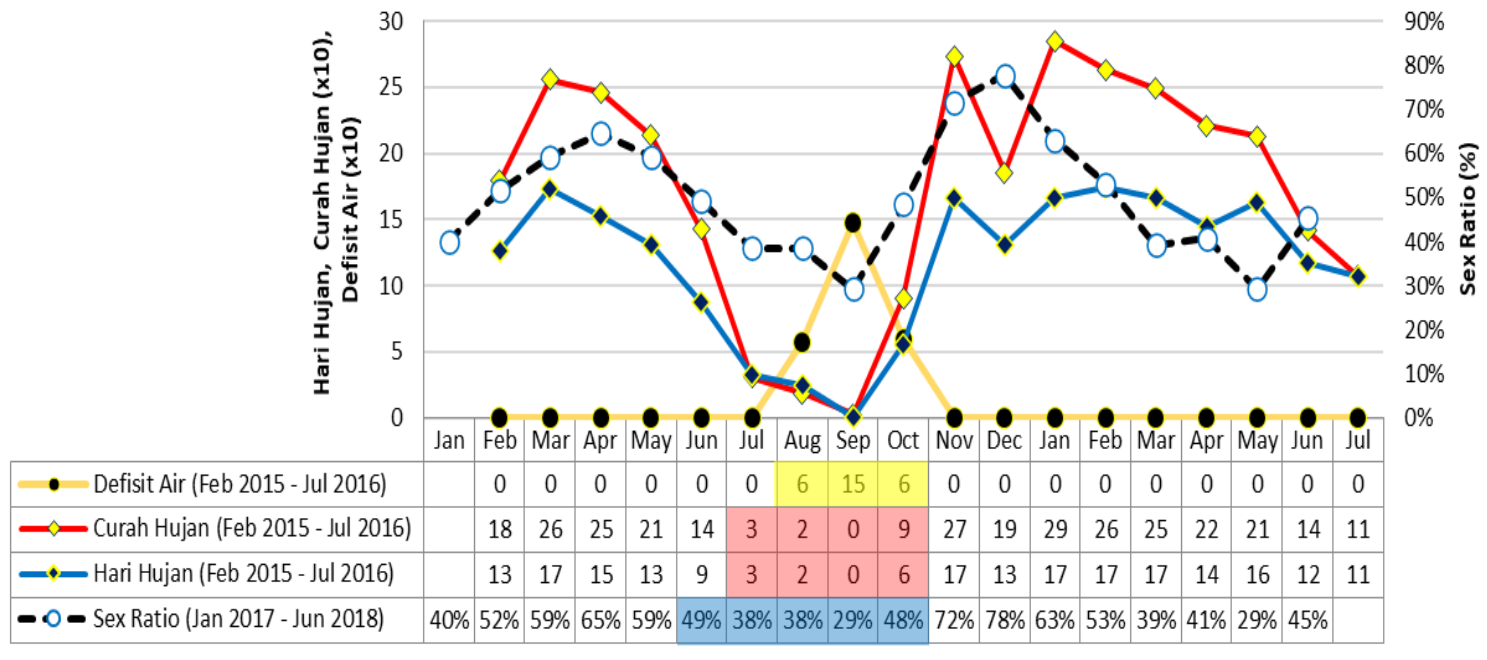

Gambar 4. Korelasi hari hujan, curah hujan dan defisit air terhadap sex ratio bunga kelapa sawit

Hasil analisa regresi menunjukkan bahwa curah hujan dan hari hujan memberikan pengaruh terhadap sex ratio pada saat 23 bulan sebelum panen (BSP), sedangkan defisit air menunjukkan pengaruh pada saat 24 BSP. Hal ini kemungkinan karena penentuan nilai defisit air juga dipengaruhi oleh keseimbangan air pada bulan sebelumnya, berbeda dengan curah hujan dan hari hujan yang nilainya tidak dipengaruhi oleh nilai bulan sebelumnya. Hal ini sesuai dengan Nababan (2017) menjelaskan bahwa defisit air diduga dapat mempengaruhi produksi kelapa sawit pada beberapa bulan selanjutnya. Persamaan regresi linear berganda disajikan dalam bentuk rumus berikut:

$$
\mathrm{Y}=36,638+20,790 \mathrm{X} 1-5,370 \mathrm{X} 2+0,341 \mathrm{X} 3
$$

Keterangan :

$\mathrm{X} 1=$ defisit air

$\mathrm{X} 2=$ hari hujan,

$\mathrm{X} 3=$ curah hujan

Berdasarkan Gambar 4 di atas diketahui bahwa nilai curah hujan dan hari hujan yang tinggi berdampak positif dalam peningkatan sex ratio, sedangkan curah hujan dan hari hujan yang rendah menyebabkan pengaruh negatif berupa penurunan sex ratio. Defisit air yang tinggi berpengaruh terhadap penurunan sex ratio, sedangkan pada kondisi normal (tidak terjadi deficit air) nilainya terlihat fluktuatif mengikuti kurva curah hujan dan hari hujan.

Air sangat diperlukan tanaman untuk mengangkut unsur-unsur hara dan zat-zat terlarut lain di dalam tanaman serta untuk produksi gula pada proses fotosintesis, sehingga tanaman memperoleh energi untuk pertumbuhan dan berkembanga menjadi dewasa (Hidayat, 2013a). Mekanisme pengaruh ketersediaan air terhadap sex ratio bersama faktor lainnya dijelaskan oleh Adam et al., (2011) pada bagan Gambar 5.

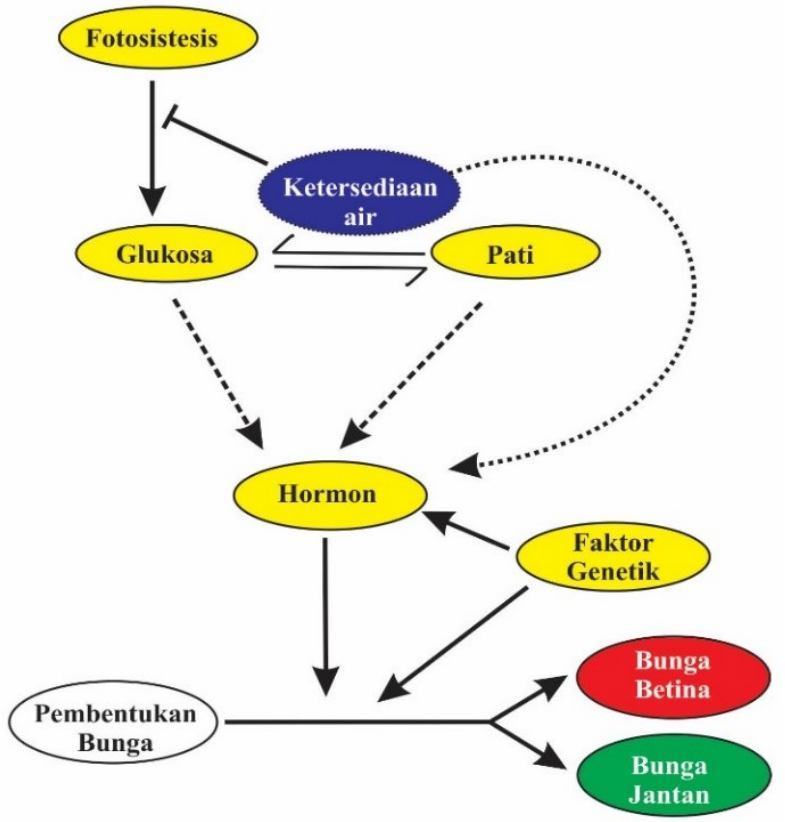

Gambar 5. Model interaksi faktor yang mempengaruhi determinasi sex bunga kelapa sawit (Sumber: Adam et al., 2011)

Menurut Sheriff (1992) tanaman sangat peka terhadap kekurangan air, hal ini dapat berakibat pada pengurangan pembentukan dan pembentangan daun sehingga fotosintesis tanaman akan terganggu dan terjadi penurunan produktivitas tanaman. Defisit air dapat menghambat pertumbuhan dan perkembangan bunga serta buah pada kelapa sawit sehingga 
berdampak dalam menurunkan produksi kelapa sawit (Murtilaksono et al., 2007) serta penurunan BJR (Simanjuntak et al., 2014), namun defisit air di bawah $50 \mathrm{~mm}$ masih belum mempunyai dampak terhadap produktivitas (Tjedahwati, 2014). Kekeringan pada bagian vegetatif menyebabkan penutupan stomata dan menghambat pertumbuhan pelepah, sedangkan kekeringan pada bagian generatif menyebabkan penurunan produksi tanaman. Ketersediaan air juga sangat berpengaruh pada kegiatan pemupukan karena air berperan sebagai zat pelarut yang melarutkan unsur hara sehingga dapat diserap oleh akar tanaman (Supriyanto, 2007). Beirnaert (1935) menduga bahwa rasio asimilasi karbon pada penyerapan nitrogen adalah faktor kunci yang menentukan sex ratio. Dibandingkan dengan tanaman berbunga secara keseluruhan, kelapa sawit menunjukkan fenotipik plastisitas relatif rendah terhadap pembentukan secara keseluruhan, sementara cadangan karbon pada tanaman memberikan rata-rata kesesuaian yang lebih untuk menopang ketidakseimbangan source-sink terhadap variabilitas iklim (Legros et al., 2009c). Wirianata (2014) menjelaskan bahwa source merupakan tempat utama fotosintesis (daun), sedangkan sink merupakan tempat konsumsi atau penyimpanan fotosintat (akar, tunas, biji dan buah). Legros et al., (2009a) melaporkan bahwa salah satu unsur utama yang bekerja terhadap ketidakseimbangan source - sink pada kelapa sawit sebagian besar terdiri dari glukosa dan pati. Pati diketahui sebagai cadangan utama terhadap ketidakseimbangan source - sink tetapi tidak pada glukosa (Legros et al., 2009c). Kadar glukosa ditemukan semakin menurun dalam merespon tandan membrondol (Legros et al., 2009b). Adam et al., (2011) menyatakan bahwa gibberellic acid berpengaruh meningkatkan produksi bunga jantan dan menurunkan produksi bunga betina tanaman kelapa sawit. Pengaruh gibberellic acid pada spesies tanaman menunjukkan respon yang berbeda. Seperti yang dilaporkan oleh Fuchs et al., (1977) bahwa perlakuan gibberellic acid meningkatkan produksi bunga jantan pada tanaman mentimun, sedangkan pada tanaman jagung meningkatkan produksi bunga betina (Dellaporta and Calderon, 1994). Peranan hormon dalam merespon perubahan lingkungan pada tanaman kelapa sawit (Gambar 5) adalah sebagai perantara sinyal elemen antara keseimbangan air dan determinasi sex, sedangkan faktor metabolisme kemungkinan bertindak dalam pembentukan molekul hormon (Adam et al., 2011).

\section{Pemodelan Data OPD untuk Estimasi Distribusi Produksi Bulanan}

Akurasi pendugaan produksi kelapa sawit di lapangan bervariasi antar kebun dan antar musim (Sulistyo, 2010). Pemodelan distribusi yang dibuat rata-rata masih menggunakan data budget perusahaan, kemudian untuk distribusinya menggunakan data BBC. Estimasi produksi per bulan menggunakan data OPD perlu dikaji dengan memisahkan data luasan berdasarkan tahun tanam dan jenis tanah untuk kemudian dikombinasikan dengan data BJR. Hasil uji anova antara estimasi distribusi bulanan dan produksi aktual menunjukkan tidak berbeda nyata dengan $\mathrm{f}$ hitung sebesar $0,010<\mathrm{f}$ tabel sebesar 3,40. Selisih antara distribusi produksi aktual dan pendugaan distribusi pada Jan - Sept 2017 sebesar 0 - 4\%. Hal ini memenuhi syarat toleransi kesalahan suatu pendugaan produksi yaitu $+5 \%$ (Annisa, 2013). Berdasarkan Gambar 6 terlihat estimasi produksi bulan Juni - September 2017 menunjukkan posisi di bawah persentase produksi aktual. Perbedaan hasil tersebut kemungkinan karena tandan mengalami aborsi, namun faktor utama karena BJR mengalami kenaikan sehingga produksi aktual lebih tinggi. Jumlah tandan merupakan salah satu faktor utama yang berpengaruh dalam menghitung nilai potensi produksi kelapa sawit, namun kenaikan atau penurunan berat janjang juga mempunyai pengaruh besar terhadap akurasi produksi pada tahun tersebut. Hakim (2007) menyatakan bahwa perkiraan bunga tidak terbentuk (aborsi) dan jumlah produksi berbanding lurus dengan kekeringan yang ditandai dengan defisit air dan lamanya hujan tidak turun. Penyebab terjadinya aborsi (bunga gugur) adalah kurangnya karbohidrat untuk perkembangan bunga, defisit air, pengurangan daun yang terlalu banyak sehingga tanaman mengalami cekaman (Corley, 1973). 


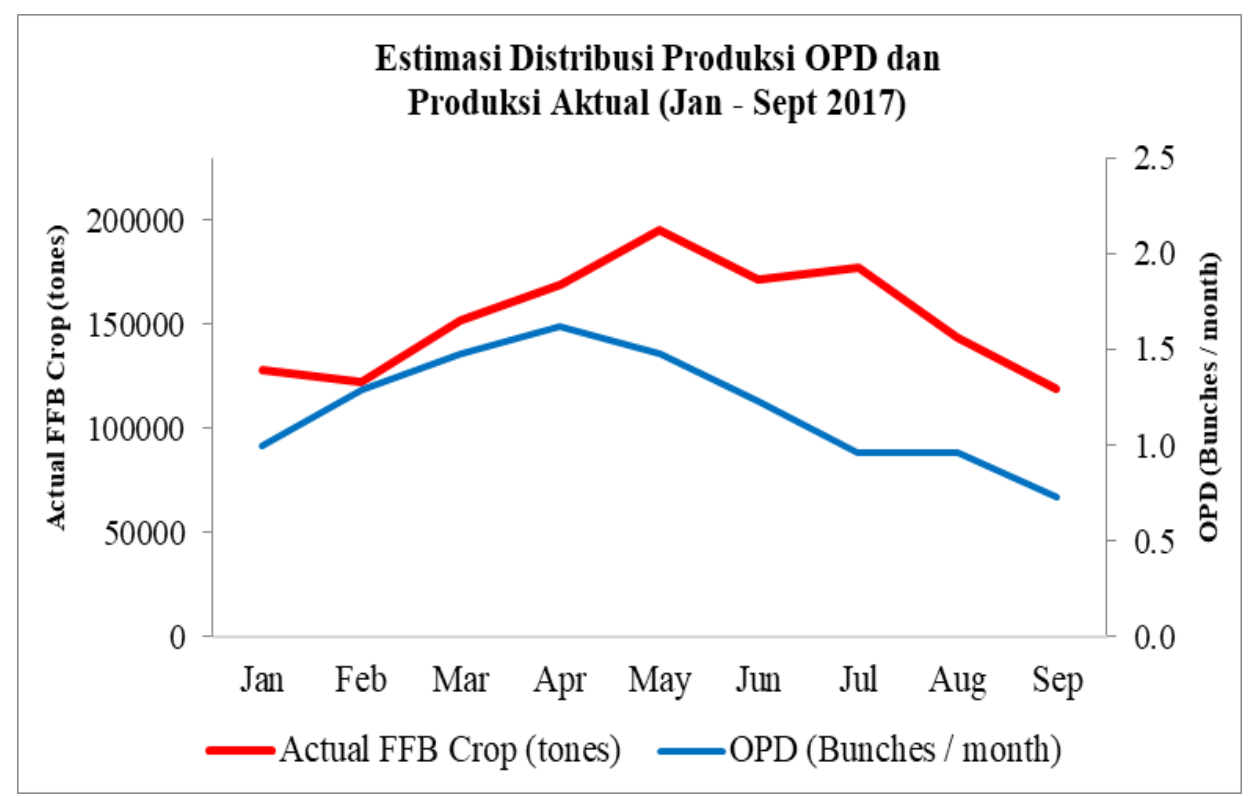

Gambar 6. Perbandingan estimasi distribusi produksi OPD dan produksi aktual (Jan - Sept 2017)

\section{KESIMPULAN}

Kesimpulan dari penelitian ini adalah curah hujan, hari hujan dan defisit air pada 23-24 bulan sebelum panen berpengaruh terhadap sex ratio kelapa sawit. Curah hujan dan hari hujan yang tinggi (tanpa defisit air) berdampak positif dalam meningkatkan persentase sex ratio, sedangkan defisit air yang tinggi berpengaruh terhadap penurunan sex ratio. Estimasi distribusi produksi bulanan berdasarkan metode OPD menunjukkan tidak berbeda nyata terhadap produksi aktual sehingga dapat dipergunakan untuk menduga distribusi produksi bulanan tanaman kelapa sawit untuk periode 1-1.5 tahun kedepan.

\section{Daftar pustaka}

Adam, H., Collin, M., Richaud, F., Beulé, T., Cros, D., Omoré, A., ... Tregear, J. W. (2011). Environmental regulation of sex determination in oil palm: Current knowledge and insights from other species. Annals of Botany, 108(8), 1529-1537. https://doi.org/10.1093/aob/mcr151

Annisa, A. (2013). Pemanfaatan Data Agroklimatologi untuk Menduga Produksi Kelapa Sawit (Elaeis guineensis Jacq.) di Bangun Koling Estate.

Darlan, N. H., Pradiko, I., Winarna, W., \& Siregar, H. S. (2015). Dampak Kekeringan dan Gangguan Asap Akibat El Nino 2015 Terhadap Performa Tanaman Kelapa Sawit di Bagian Selatan Sumatera. Jurnal Tanah dan Iklim, 40(2), 113120.
Hakim, M. (2007). Kelapa Sawit: Teknis Agronomis dan Manajemennya.

Hidayat, T. C., Harahap, I. Y., Pangaribuan, Y., Rahutomo, S., Harsanto, W. A., \& Fauzi, W. R. (2013a). Air dan Kelapa Sawit.

Hidayat, T. C., Harahap, I. Y., Pangaribuan, Y., Rahutomo, S., Harsanto, W. A., \& Fauzi, W. R. (2013a). Bunga, Buah dan Produksi Kelapa Sawit.

Hoffmann, M. P., Vera, A. C., Wijk, V. M. T., Giller, K. E., Oberthur, T., Donough, C., \& Whitbread, A. M., (2014). Simulating potensial growth and yield of oil palm (Elaeis guineensis) with palmsim: model description, evaluation and application. Agricultural Systems, 131, 1-10. https://doi.org/10.1016/j.agsy.2014.07.006

Legros, S., Mialet-Serra, I., Caliman, J. P., Siregar, F. A., Clément-Vidal, A., \& Dingkuhn, M. (2009). Phenology and growth adjustments of oil palm (Elaeis guineensis) to photoperiod and climate variability. Annals of Botany, 104(6), 11711182. https://doi.org/10.1093/aob/mcp214

Legros, S., Mialet-Serra, I., Caliman, J. P., Siregar, F. A., Clement-Vidal, A., Fabre, D., \& Dingkuhn, M. (2009). Phenology, growth and physiological adjustments of oil palm (Elaeis guineensis) to sink limitation induced by fruit pruning. Annals of Botany, 104(6), 1183-1194. https://doi.org/10.1093/aob/mcp216

Legros, S., Mialet-Serra, I., Clement-Vidal, A., Caliman, J. P., Siregar, F. A., Fabre, D., \& 
Dingkuhn, M. (2009). Role of transitory carbon reserves during adjustment to climate variability and sourcesink imbalances in oil palm (Elaeis guineensis). Tree Physiology, 29(10), 11991211. https://doi.org/10.1093/treephys/tpp057

Murtilaksono, K., Siregar, H. H., \& Darmosarkoro, W. (2007). Model Neraca Air di Perkebunan Kelapa Sawit. Jurnal Penelitian Kelapa Sawit, 15(1), 21-35.

Nababan, A. (2017). Analisis Faktor Produksi Terhadap Pencapaian Produktivitas Kelapa Sawit Di Kebun Sei Batang Ulak, Pt Ciliandra Perkasa (First Resources) Riau.

Nawfetrias, W. (2015). Isolasi dan Karakterisasi Gen Pembungaan pada Kelapa Sawit (Elaeis guineensis Jacq.).

Pasaribu, S. M. 2013. Pengaruh Perlakuan Teknik Konservasi Air Terhadap Evapotranspirasi Tanaman Kelapa Sawit.

Prasetyo, A.E., \& Agus S. (2012). Meningkatkan Fruit Set Kelapa Sawit dengan Teknik Hatch \& Carry Elaeidobius kamerunicus.

Rahutomo, S., Siregar, H. H., \& Sutarta, E. S. (2007). Irigasi pada Perkebunan Kelapa Sawit: Sebuah Tinjauan. Warta PPKS, 15(1), 7-18.

Simanjuntak, L. N., Sipayung, R., \& Irsal, I. (2014). Pengaruh Curah Hujan dan Hari Hujan
Terhadap Produksi Kelapa Sawit Berumur 5, 10, dan 15 Tahun di Kebun Begerpang Estate PT. PP London Sumatera Indonesia, Tbk. Jurnal Online Agroekoteknologi, 2(3), 1141 1151.

Siregar, H. H., Iman Yani Harahap, Witjaksana Darmosarkoro, Edy Sigit Sutarta, dan Endang Syamsuddin. Seri Buku Saku 10; Antisipasi \& Penanggulangan Pengaruh Kekeringan pada Kelapa Sawit. Medan : PPKS.

Sulistyo, H. (2010). Identifikasi parameter agronomi untuk pengembangan taksasi produksi kelapa sawit (Elaeis guineensis Jacq.) di Angsana Estate, PT. Ladang Rumpun Suburabadi Minamas Plantation, Tanah Bumbu, Kalimantan Selatan.

Tjedahwati, T. (2014). Komponen Neraca Air Tanaman Kelapa Sawit di PTPN VIII, Cimulang Bogor.

Wirianata, H. (2014). Pengelolaan Kanopi Kelapa Sawit. Presentasi pada BGA Executive Education. 